\title{
GC-MS analysis of cuticular waxes and evaluation of antioxidant and antimicrobial activity of Chaenomeles cathayensis and $\mathrm{Ch} . \times$ californica fruits
}

\author{
Y. V. Lykholat*, N. O. Khromykh*, O. O. Didur*, T. V. Sklyar*, T. A. Holubieva**, \\ T. Y. Lykholat*, K. V. Lavrentieva*, O. V. Liashenko* \\ *Oles Honchar Dnipro National University, Dnipro, Ukraine \\ **National University of Life and Environmental Sciences of Ukraine, Kyiv, Ukraine
}

Article info

Received 25.09.2021 Received in revised form 18.10.2021

Accepted 20.10.2021

Oles Honchar Dnipro National University Gagarin av., 72,

Dnipro, 49010, Ukraine. Tel.: +38-050-487-87-17. E-mail:khromykhn@ukr.net

National University of Life and Environmental Sciences of Ukraine, Heroiv Oborony st., 15, Kyiv, 03041, Ukraine. Tel.: +38-097-673-33-10. E-mail:

golubev.mon@gmail.com

Lykholat, Y. V., Khromykh, N. O., Didur, O. O., Sklyar, T. V., Holubieva, T. A., Lykholat, T. Y., Lavrentieva, K. V., \& Liashenko, $O$. V. (2021). GC-MS analysis of cuticular waxes and evaluation of antioxidant and antimicrobial activity of Chaenomeles cathayensis and Ch. $\times$ californica fruits. Regulatory Mechanisms in Biosystems, 12(4), 718-723. doi:10.15421/022199

Fruit extracts of the Chaenomeles species are a rich source of compounds having health-promoting properties, while their distribution between the species and cultivars varies significantly depending on both genotype and environmental threats. This study aimed at discovering antioxidant and antimicrobial potential of the secondary metabolites of fruit and waxes of fruit cuticular of introduced Ch. cathayensis and Ch. $\times$ californica plants. The sum of detected polyphenols in the isopropanolic fruit extracts varied slightly between the species, while significant excesses in indices were seen for both species peel extracts as compared to pulp extracts. Antimicrobial assays carried out by disc diffusion method showed notable activity of the fruit peel and pulp extracts of both species against all tested Gram-negative and Gram-positive bacterial strains, and two Candida strains as well. Pseudomonas aeruginosa strain was the most resistant to the action of both fruit extracts, especially peel extracts of Ch. cathayensis fruits. As identified by gas chromatography-mass spectrometry (GC-MS) assays, chloroformic extracts from the fruits of cuticular waxes of Ch. cathayensis and $C h . \times$ californica contained six prevailing fractions: aldehydes, alkanes, alcohols, esters, fatty acids and various terpenoids. The predominant compounds were tetrapentacontane (21.8\% of total amount) and heptacosanal (23.1\% of total), respectively in the cuticular waxes of Ch. cathayensis and Ch. $\times$ californica. Cinnamaldehyde, cis-9-hexadecenal, hexadecanoic acid, oleic acid, olean-12-ene-3,28-diol (3. beta), lupeol, diisooctyl phthalate, 9-octadecenoic acid, 1,2,3-propanetriyl ester, 1,3,12-nonadecatriene-5,14-diol and some other identified compounds are well-known for their bioactivity, indicating the feasibility of studying the antimicrobial potential of plant fruits.

Keywords: Chaenomeles fruits; phenolic compounds; cuticular waxes; antimicrobial activity.

\section{Introduction}

Species Chaenomeles cathayensis (Hemsl.) Schneider (Chinese quince) is a native plant in China and may be found in the wild, while $C h . \times$ californica Clarke ex Weber is a tri-species hybrid [Ch. cathayensis $\times$ $($ Ch. $\times$ superba), Californica group] as Yeung (2000) reported. Plants of all species belonging to the genus Chaenomeles Lindley (Rosaceae family) are well known as a rich source of bioactive compounds that can provide the impressive spectrum of useful properties (Miao et al., 2016). The preparations from the fruits, leaves and twigs of various Chaenomeles plants have been used in traditional medicine for treating pneumonia, bronchitis (Han et al., 2016), as well as vitamin C deficiency syndrome, rheumatism, cholera, dysentery, and beriberi (Zhang et al., 2014). During the recent years, numerous investigations confirmed the high prophylactic and therapeutic effects of plant extracts from the commonest Chaenomeles species. Significant anti-carcinogenic action against colon cancer (Gorlach et al., 2011) and breast cancer (Lewandowska et al., 2013) was exhibited by the extracts from Ch. japonica fruits, and for extracts from leaves of Ch. japonica - against glioblastoma cells (Zvikas et al., 2021). Immunoregulatory and antiparkinsonian properties were demonstrated by the extracts from $C h$. speciosa fruits (Zhang et al., 2014). Hepatoprotective activity was shown by the fruit extracts of Ch. thibetica (Ma et al., 2016) and Ch. japonica (Baranowska-Bosiacka et al., 2017). Strong anti-inflammatory effect along with cytotoxic activities against cultured human tumour cell lines were exhibited by the extracts of Ch. speciosa twigs (Suh et al., 2017), while antioxidant and anti-inflammatory effects were shown by the $C h$. sinensis leaf extracts (Han et al., 2016). Hypoglycemic effect of $C h$. japonica fruit polyphenols may have preventive anti-diabetic action (ZakłosSzyda \& Pawlik, 2018). In general, most of the studies we mentioned have indicated the association between bioactivities of Chaenomeles plant extracts and the polyphenols content in the fruits and other plant organs.

In the recent decades, the remarkable properties of Chaenomeles plants have gained wide popularity, and some species were successfully introduced to a number of European countries (Rumpunen, 2002), and to Ukraine as well (Khromykh et al., 2018; Lykholat et al., 2019). However, the ability of introduced plants to accumulate bioactive compounds and retain beneficial properties in a new environment is not fully clear. The survival of plants in a new habitat involves all plant adaptive mechanisms, including the multiple functions of the cuticle and cuticular waxes. The protection of plants from external environments and biotic or abiotic stresses is partly provided by the cuticular waxes as the first defensive barrier of plant organisms. The major components of cuticular wax are very long chain fatty acids and different derivatives (Trivedi et al., 2019) contents of which vary significantly depending on plant species and the growth conditions (Lykholat et al., 2018). However, the chemical composition and defensive properties of Chaenomeles plant cuticular waxes are poorly studied. The objective of this study was comparing the introduced natural and hybrid Chaenomeles species regarding accumulation of polyphenols, cuticular waxes composition, and antimicrobial activity of plant fruits. 


\section{Materials and methods}

Fruits of Ch. cathayensis and Ch. $\times$ californica were taken from the Botanical Garden of the Oles Honchar Dnipro National University (4826'07' N, 3502'34' E, Dnipro city, Ukraine). There, several plants of the genus Chaenomeles Lindl. were introduced more than 25 years ago in the steppe climate with low precipitation ( $473 \mathrm{~mm}$ average, but $265 \mathrm{~mm}$ in dry years) and sharp temperature changes. Ripe fruits of the Chaenomeles plants were collected in the first half of September 2021, packed in plastic containers and immediately delivered to the laboratory.

Plant extracts for polyphenols content determination and bioassays were prepared using $80 \%$ isopropanol. Briefly, $2.0 \mathrm{~g}$ weighed portion of fresh fruit (peel and flesh as the separated samples) was triturated with 20 $\mathrm{ml}$ of isopropanol and kept for 24 hours at the room temperature in dark with occasional shaking. Then, the extracts were filtered through the paper filters, and the total volume was divided into two parts intended for different studies. Total polyphenols content (TPC), total flavonoids content (TFC), free phenolic acids content (PAC), total antioxidant capacity (TAC), and reducing power (RP) were determined in the crude extracts obtained. For the antimicrobial assays, crude extracts were dried at $45^{\circ} \mathrm{C}$ using a rotary evaporator IKA ${ }^{\circledR}$ RV 10 (Germany), and a corresponding amount of solid residue was dissolved in isopropanol.

Total polyphenols content (TPC) in the fruit peel and pulp extracts was determined using spectrophotometric method with Folin-Ciocalteu reagent (Singleton et al., 1999); the absorbance was measured at $726 \mathrm{~nm}$, and the results were then calculated using a calibration graph prepared on the solutions of Gallic acid (GA) and expressed as mg GA equivalents per $100 \mathrm{~g}$ of wet weight (mg GA/100 $\mathrm{g} \mathrm{WW}$ ). Total flavonoids content (TFC) in fruit peel and pulp was determined by aluminum chloride spectrophotometric method (Pękal \& Pyrzynska, 2014); the absorbance was measured at $425 \mathrm{~nm}$; results were calculated using a calibration graph prepared on the rutin $(\mathrm{Ru})$ solutions and expressed as rutin equivalents per $100 \mathrm{~g}$ (mg Ru/100 g WW). Free phenolic acids content (FAC) was determined using a spectrophotometric method described by Gawron-Gzella et al. (2012) with Arnov's reagent (10.0 g of sodium molybdate, $10.0 \mathrm{~g}$ sodium nitrite in $100.0 \mathrm{~mL}$ of water); absorbance at $490 \mathrm{~nm}$ was measured; caffeic acid (CA) was used as the standard, and the results were expressed in caffeic acid equivalents (mg CA/100 g WW). Reducing power (RP) of the plant fruit extracts was evaluated using potassium ferricyanide method (Pulido et al., 2000); the absorbance was measured at $700 \mathrm{~nm}$, and the results were expressed in mg Ascorbic acid (AA) equivalents (mg AA/100 g WW). Evaluation of total antioxidant capacity (TAC) of fruit peel and pulp was carried out in accordance with Prieto et al. (1999) using the reagent solution ( $0.6 \mathrm{M}$ sulfuric acid, $28 \mathrm{mM}$ sodium phosphate, and $4 \mathrm{mM}$ ammonium molybdate); after the incubation in $95^{\circ} \mathrm{C}$ for $90 \mathrm{~min}$, the absorbance at $695 \mathrm{~nm}$ was measured against blank; the results were calculated using a calibration graph prepared on the solutions of ascorbic acid, and expressed as mg AA equivalents (mg AA/100 g WW).

Chloroform was used for extraction from Ch. cathayensis and Ch. $\times$ californica fruit cuticular waxes (Buschhaus et al., 2007) through immersing fruits in a solvent for 60 seconds, followed by solvent evaporation at $40^{\circ} \mathrm{C}$ using a rotary evaporator (IKA ${ }^{\circledR} \mathrm{RV} 10$, Germany). Obtained solid fraction was stored at $4{ }^{\circ} \mathrm{C}$; for $\mathrm{GC}-\mathrm{MS}$ analysis, dry residue was dissolved in chloroform and filtered through a syringe filter. Chloroformic extracts were subjected to gas chromatography - mass spectrometry (GCMS) analysis using Shimadzu GCMS-QP 2020 El equipped with Rxi ${ }^{\mathbb{B}}$ $5 \mathrm{~ms}$ column $(30 \mathrm{~m} \times 0.25 \mathrm{~mm}$, film thickness $0.25 \mu \mathrm{m})$ containing $5 \%$ dipheny $1 / 95 \%$ dimethyl polysiloxane as a fixed liquid phase. The column temperature equaled $50^{\circ} \mathrm{C}$, with $5 \mathrm{~min}$ initial hold, and then programmed temperature gradient increased to $300^{\circ} \mathrm{C}$ at the rate of $15^{\circ} \mathrm{C}$ per min, and kept constant at $300^{\circ} \mathrm{C}$ for $10.5 \mathrm{~min}$. The carrier gas helium was passed at the flow rate of $54 \mathrm{~mL} / \mathrm{min}$. Injector temperature was $300{ }^{\circ} \mathrm{C}$; sample volume was $1 \mu \mathrm{L}$. Mass Spectrum Library 2014 for GC-MS (O2125401310) was used to identify the separated compounds by comparing the mass spectra obtained with those stored in the library database (National Institute of Standards and Technology library similarity index, NIST14.lib, NIST14s.lib). The content of individual compounds in the fruit cuticular waxes was estimated through the corresponding peak area and expressed as a percentage of the total.

Antimicrobial activity of the isopropanolic extracts from $\mathrm{Ch}$. $\mathrm{Ca}$ thayensis and Ch. $\times$ californica fruit peel and pulp were tested using the disc diffusion method described by Bhimba et al. (2012). The test strains of microorganisms were taken from the culture collection of Microbiology, Virology and Biotechnology Department of Oles Honchar University. Four Gram-negative bacteria, namely Erwinia dissolvens (strain 170), Escherichia coli (strain B 906), Pseudomonas aeruginosa (strain B 907), Klebsiella pneumonia (strain B 920), and five Gram-positive bacteria, including Micrococcus lysodeikticus (strain 2665), Staphylococcus aureus (strain B 904), Staphylococcus aureus (strain B 209), Staphylococcus epidermidis (strain ATCC 149), Staphylococcus epidermidis (strain 919), and two fungal strains (Candida albicans (clinical strain) and Candida lipolytica (strain B 504) were tested. Petri plates containing meat-peptone agar (MPA) medium were inoculated with $10^{9} \mathrm{CFU}$ (colony forming units) of suspension of microorganisms. Sterile paper discs (6 mm diameter) were impregnated with $10 \mu \mathrm{L}$ of crude isopropanolic fruit extracts and placed on the agar surface, followed by incubation of plates at $37^{\circ} \mathrm{C}$ for $24 \mathrm{~h}$. Ofloxacin ( $5.0 \mu \mathrm{g}$ per disc) was used as the positive control for the bacterial strains; itraconazole $10.0 \mu \mathrm{g}$ was used as the positive control for the fungal strains. Antimicrobial activity of the fruit peel and pulp extracts was expressed as the diameter of the inhibition zone ( $\mathrm{mm}$ ) around the discs along with disc diameter.

All bioassays were carried out in five replications. Statistical processing of the experimental results was based on analysis of variance (ANOVA). The data obtained were expressed as the mean \pm standard deviation $(x \pm \mathrm{SD})$, and the differences between the means were compared with Tukey's HSD. All differences were considered to be statistically significant at $\mathrm{P}<0.05$.

\section{Results}

The contents of phenolic compounds in Ch. cathayensis and Ch. $\times$ californica fruits revealed the domination of polyphenols in fruit peel, and the similarity in the ratio of the peel and pulp indicators of both plant species (Table 1)

Table 1

Phenolic compounds content and antioxidant activity of Chaenomeles fruits $(\mathrm{x} \pm \mathrm{SD}, \mathrm{n}=5)$

\begin{tabular}{|c|c|c|c|c|c|}
\hline \multirow{2}{*}{ Index } & \multirow{2}{*}{ Indicator unit } & \multicolumn{2}{|c|}{ Ch. cathayensis } & \multicolumn{2}{|c|}{ Ch. $\times$ californica } \\
\hline & & peel & pulp & peel & pulp \\
\hline Total polyphenol content & $\mathrm{mg} \mathrm{GA} / 100 \mathrm{~g} \mathrm{FW}$ & $1441.2 \pm 5.6^{\mathrm{a}}$ & $533.0 \pm 4.1^{\mathrm{b}}$ & $1240.9 \pm 5.6^{\mathrm{c}}$ & $534.2 \pm 5.6^{b}$ \\
\hline Total flavonoid content & $\mathrm{mg} \mathrm{Ru} / 100 \mathrm{gFW}$ & $79.45 \pm 4.39^{\mathrm{a}}$ & $31.59 \pm 2.87^{b}$ & $45.11 \pm 1.77^{\mathrm{c}}$ & $36.60 \pm 1.88^{\mathrm{b}}$ \\
\hline Free phenolic acids content & $\mathrm{mg} \mathrm{CA} / 100 \mathrm{~g} \mathrm{FW}$ & $95.36 \pm 0.74^{\mathrm{a}}$ & $36.07 \pm 0.42^{b}$ & $79.42 \pm 1.05^{\mathrm{c}}$ & $36.20 \pm 0.06^{b}$ \\
\hline Reducing power & $\mathrm{mg} \mathrm{AA} / 100 \mathrm{~g} \mathrm{FW}$ & $1871.9 \pm 17.4^{\mathrm{a}}$ & $518.6 \pm 15.1^{\mathrm{b}}$ & $1598.2 \pm 7.6^{\mathrm{c}}$ & $542.2 \pm 7.7^{\mathrm{d}}$ \\
\hline Total antioxidant capacity & mg AA/100 g FW & $3273.0 \pm 4.6^{\mathrm{a}}$ & $1703.1 \pm 5.4^{\mathrm{b}}$ & $3277.8 \pm 31.4^{\mathrm{a}}$ & $1578.7 \pm 98.3^{\mathrm{b}}$ \\
\hline
\end{tabular}

Note: different letters indicate the values significantly differing one from another within a line of the Table according to the results of comparison using the Tukey test $(\mathrm{P}<0.05)$.

The total content of phenolic compounds, total flavonoids and free phenolic acids content in Ch. cathayensis fruit peel exceeded the corresponding indicators in the pulp by $2.7,2.5$ and 2.6 times respectively. In the fruits of $\mathrm{Ch} . \times$ californica, the above-mentioned excesses were smaller, amounting to $2.3,1.2$ and 2.2 times respectively. Antioxidant activity of the peel extracts of Ch. cathayensis was higher compared with the pulp ones: by 3.6 and 1.9 times, respectively for reducing power and total antioxidant property. Similarly, the differences between the antioxidant activity indices of $C h$. $\times$ californica fruit peel and pulp were 3.0 and 2.1 times respectively. In general, total contents of phenolic compounds, total flavonoids and free phenolic acids content as well as the antioxidant potential of Ch. cathayensis fruits prevailed over the corresponding levels of $C h . \times$ 
californica fruits (by 1.1-1.4 times). However, high correlation was seen between the total polyphenols content and total antioxidant capacity of the whole fruits of both species $(r=0.94$ and $r=0.90$, respectively for Ch. cathayensis and Ch. $\times$ californica). Antimicrobial assays carried out by the disc diffusion method showed bioactivity of the isopropanolic extracts from peel and pulp of both Ch. cathayensis and Ch. $\times$ californica fruits against all tested strains (Table 2). The isopropanolic extracts of C. cathayensis fruit peel showed more notable growth-inhibiting effects on the Gram-negative bacteria, except $P$. aeruginosa strain, while
M. lysodeikticus and all Staphylococcus strains were more resistant, especially S. aureus B904 and S. epidermidis ATCC149. At the same time, Gram-positive bacteria, especially M. lysodeikticus and S. aureus B209 were more sensitive to the action of extracts from $C h$. cathayensis fruit pulp. Both peel and pulp extracts from Ch. cathayensis fruits exhibited high activity against E. coli $\mathrm{B} 906$ and K. pneumoniae strains, and the lowest activity against $P$. aeruginosa. With regard to the fungal strains, C. albicans was more inhibited by Ch. cathayensis fruit peel extract, when C. lipolytica was more sensitive to the action of fruit pulp extracts.

Table 2

Diameter of inhibition zones $(\mathrm{mm})$ caused by the Chaenomeles fruits isopropanolic extracts $(\mathrm{x} \pm \mathrm{SD}, \mathrm{n}=5)$

\begin{tabular}{|c|c|c|c|c|c|}
\hline \multirow{2}{*}{ Test-culture } & \multicolumn{2}{|c|}{ Ch. cathayensis extracts } & \multicolumn{2}{|c|}{ Ch. $\times$ californica extracts } & \multirow{2}{*}{ Positive control $^{1}$} \\
\hline & peel, $42.5 \mu \mathrm{g} / \mu \mathrm{L}$ & pulp, $45.5 \mu \mathrm{g} / \mu \mathrm{L}$ & peel, $42.5 \mu \mathrm{g} / \mu \mathrm{L}$ & pulp, $45.5 \mu \mathrm{g} / \mu \mathrm{L}$ & \\
\hline Erwinia dissolvens 170 & $13.33 \pm 0.26^{\mathrm{a}}$ & $10.88 \pm 0.31^{\mathrm{b}}$ & $11.38 \pm 0.17^{b}$ & $8.53 \pm 0.17^{\mathrm{c}}$ & $22.78 \pm 0.24^{\mathrm{d}}$ \\
\hline Escherichia coli B906 & $12.88 \pm 0.22^{\mathrm{a}}$ & $12.70 \pm 0.29^{\mathrm{a}}$ & $11.48 \pm 0.35^{\mathrm{b}}$ & $13.23 \pm 0.31^{\mathrm{a}}$ & $26.80 \pm 0.42^{\mathrm{c}}$ \\
\hline Pseudomonas aeruginosa B 907 & $7.70 \pm 0.18^{\mathrm{a}}$ & $8.93 \pm 0.17^{b}$ & $8.90 \pm 0.22^{b}$ & $8.58 \pm 0.25^{\mathrm{b}}$ & $14.68 \pm 0.48^{c}$ \\
\hline Micrococcus lysodeikticus 2665 & $8.73 \pm 0.17^{\mathrm{a}}$ & $12.68 \pm 0.33^{\mathrm{b}}$ & $9.43 \pm 0.17^{\mathrm{c}}$ & $8.43 \pm 0.22^{\mathrm{a}}$ & $12.23 \pm 0.15^{\mathrm{b}}$ \\
\hline Klebsiella pneumonia B 920 & $11.20 \pm 0.32^{\mathrm{a}}$ & $11.58 \pm 0.28^{\mathrm{a}}$ & $11.08 \pm 0.25^{\mathrm{a}}$ & $9.20 \pm 0.18^{\mathrm{b}}$ & $24.10 \pm 0.34^{\mathrm{c}}$ \\
\hline Staphylococcus aureus B904 & $8.13 \pm 0.17^{\mathrm{a}}$ & $10.60 \pm 0.14^{\mathrm{b}}$ & $9.63 \pm 0.17^{\mathrm{c}}$ & $11.38 \pm 0.15^{\mathrm{d}}$ & $34.23 \pm 0.54^{\mathrm{e}}$ \\
\hline Staphylococcus aureus B209 & $8.98 \pm 0.21^{\mathrm{ab}}$ & $11.65 \pm 0.37^{\mathrm{c}}$ & $9.50 \pm 0.16^{\mathrm{a}}$ & $8.60 \pm 0.28^{b}$ & $32.55 \pm 0.44^{\mathrm{d}}$ \\
\hline Staphylococcus epidermidis ATCC149 & $8.15 \pm 0.21^{\mathrm{a}}$ & $10.03 \pm 0.29^{b}$ & $10.05 \pm 0.21^{\mathrm{b}}$ & $12.05 \pm 0.17^{\mathrm{c}}$ & $26.80 \pm 0.73^{\mathrm{d}}$ \\
\hline Staphylococcus epidermidis B919 & $9.35 \pm 0.26^{\mathrm{a}}$ & $11.18 \pm 0.22^{b}$ & $9.95 \pm 0.26^{\mathrm{ac}}$ & $10.15 \pm 0.19^{c}$ & $26.60 \pm 0.57^{\mathrm{d}}$ \\
\hline Candida albicans (clinical strain) & $11.23 \pm 0.19^{\mathrm{a}}$ & $10.43 \pm 0.33^{\mathrm{b}}$ & $10.53 \pm 0.25^{\mathrm{b}}$ & $10.88 \pm 0.43^{\mathrm{ab}}$ & $12.62 \pm 0.25^{\mathrm{c}}-$ itraconazole \\
\hline Candida lipolytica B 504 & $11.18 \pm 0.21^{\mathrm{a}}$ & $11.88 \pm 0.22^{\mathrm{ab}}$ & $11.48 \pm 0.17^{\mathrm{a}}$ & $12.20 \pm 0.26^{\mathrm{b}}$ & $13.29 \pm 0.25^{\mathrm{c}}-$ itraconazole \\
\hline
\end{tabular}

Notes: ${ }^{1}$ - for bacteria, discs with $5.0 \mu \mathrm{g}$ ofloxacin were used as positive control, and for C. albicans, C. lipolytica-discs with $10.0 \mu \mathrm{g}$ itraconazole; the diameter of the inhibition zones ( $\mathrm{mm}$ ), including the disc diameter $(6 \mathrm{~mm})$, are given as $\mathrm{x} \pm \mathrm{SD}$; different letters indicate the values significantly differing one from another within a line of the Table based on the results of comparison using the Tukey test $(\mathrm{P}<0.05)$.

The extracts of Ch. $\times$ californica fruit peel caused higher inhibition of Gram-negative bacteria, except $P$. aeruginosa, whereas growth inhibition of M. lysodeikticus, S. aureus B209 and S. aureus B904 was lower. The effect of $C h . \times$ californica fruit pulp extracts on the strains $E$. dissolovens, $P$. aeruginosa, M. lysodeikticus and $S$. aureus B209 was the lowest of all. At the same time, the activity of $C h . \times$ californica fruit pulp against E. coli B906, S. aureus B904 and S. epidermidis ATCC149 strains was the highest of all. Both peel and pulp extracts from $\mathrm{Ch} . \times$ californica fruits caused high inhibition of E. coli B906 and S. epidermidis ATCC149 strains, while the lowest inhibition was recorded for $P$. aeruginosa, M. lysodeikticus and S. aureus B209 strains. As for the fungal strains, both C. albicans and C. lipolytica were more sensitive to the action of $C h . \times$ californica fruit pulp extracts.

The GC-MS analysis of Ch. cathayensis fruit cuticular waxes identified 21 individual compounds in the chloroformic extract. The sum of all identified components was $97.0 \%$ of the total amount (Table 3 ).

Table 3

Chemical constituents of chloroformic extracts of the Ch. cathayensis fruit cuticular waxes

\begin{tabular}{|c|c|c|c|c|c|}
\hline Compound name & Formula & $\mathrm{RT}, \min$ & Peak area, $\%$ & Classification & $\begin{array}{l}\text { Known bioactivity } \\
\text { (References) }\end{array}$ \\
\hline 2,4-Dimethylhexane & $\mathrm{C}_{8} \mathrm{H}_{18}$ & 1.961 & 0.11 & alkane & not found \\
\hline 2-Tridecenal & $\mathrm{C}_{13} \mathrm{H}_{24} \mathrm{O}$ & 4.558 & 0.35 & aldehyde & not found \\
\hline 7-Hexadecenal & $\mathrm{C}_{16} \mathrm{H}_{30} \mathrm{O}$ & 7.604 & 1.39 & aldehyde & not found \\
\hline Octadec-9-enoic acid (syn. Oleic acid) & $\mathrm{C}_{18} \mathrm{H}_{34} \mathrm{O}_{2}$ & 8.145 & 0.18 & fatty acid & $\begin{array}{l}\text { antifungal (Walters et al., 2004); anti-inflammatory, } \\
\text { cancer preventive (Diab et al., 2021) }\end{array}$ \\
\hline Hexadecanoic acid (syn. Palmitic acid) & $\mathrm{C}_{16} \mathrm{H}_{32} \mathrm{O}_{2}$ & 8.175 & 0.19 & fatty acid & antifungal (Pourakbar et al., 2021) \\
\hline Cis-9-Hexadecenal & $\mathrm{C}_{16} \mathrm{H}_{30} \mathrm{O}$ & 8.240 & 1.28 & aldehyde & antimicrobial (Hoda et al., 2020) \\
\hline Heptacosanal & $\mathrm{C}_{27} \mathrm{H}_{54} \mathrm{O}$ & 8.581 & 14.52 & aldehyde & not found \\
\hline 9-Octadecenoic acid, 1,2,3-propanetriyl ester & $\mathrm{C}_{57} \mathrm{H}_{104} \mathrm{O}_{8}$ & 9.045 & 7.12 & fatty acid ester & antibacterial (Ololade et al., 2015) \\
\hline E,E,Z-1,3,12-Nonadecatriene-5,14-diol & $\mathrm{C}_{19} \mathrm{H}_{34} \mathrm{O}_{2}$ & 9.289 & 2.61 & alcohol & antifungal (Parveen et al., 2017). \\
\hline Olean-12-ene-3,28-diol (3.beta) & $\mathrm{C}_{30} \mathrm{H}_{50} \mathrm{O}_{2}$ & 9.563 & 3.07 & triterpenoid & antimicrobial (Catteau et al., 2018) \\
\hline 1-Heptatriacontanol & $\mathrm{C}_{37} \mathrm{H}_{76} \mathrm{O}$ & 9.871 & 0.78 & alcohol & not found \\
\hline Diisooctyl phthalate & $\mathrm{C}_{24} \mathrm{H}_{38} \mathrm{O}_{4}$ & 10.890 & 14.15 & fatty acid ester & antimicrobial (Shanab et al., 2010) \\
\hline 17-Pentatriacontene & $\mathrm{C}_{35} \mathrm{H}_{70}$ & 12.152 & 1.44 & alkene & antioxidant (Begum et al., 2016) \\
\hline Lup-20(29)-en-3-ol (3. beta) (syn. Lupeol) & $\mathrm{C}_{30} \mathrm{H}_{50} \mathrm{O}$ & 12.508 & 1.95 & pentacyclic triterpenoid & antimicrobial (Catteau et al., 2018) \\
\hline Tetrapentacontane & $\mathrm{C}_{54} \mathrm{H}_{110}$ & 12.945 & 21.75 & alkane & not found \\
\hline Z,Z-3,13-Octadecedien-1-ol & $\mathrm{C}_{18} \mathrm{H}_{34} \mathrm{O}$ & 13.327 & 0.15 & alcohol & not found \\
\hline Oleic acid, 3-(octadecyloxy)propyl ester & $\mathrm{C}_{39} \mathrm{H}_{76} \mathrm{O}_{3}$ & 13.798 & 0.69 & fatty acid ester & not found \\
\hline Tricosanal & $\mathrm{C}_{23} \mathrm{H}_{46} \mathrm{O}$ & 14.310 & 3.27 & aldehyde & not found \\
\hline Urs-12-en-28-al & $\mathrm{C}_{30} \mathrm{H}_{48} \mathrm{O}$ & 14.512 & 2.07 & aldehyde & antibacterial, antioxidant (Do Nascimento et al., 2014) \\
\hline 7,8-Epoxylanostan-11-ol-3-acetoxy- & $\mathrm{C}_{32} \mathrm{H}_{54} \mathrm{O}_{4}$ & 14.807 & 1.21 & steroid triterpenoid & antibacterial (Zubair et al., 2017) \\
\hline 1-Hentetracontanol & $\mathrm{C}_{41} \mathrm{H}_{84} \mathrm{O}$ & 15.036 & 18.67 & alcohol & not found \\
\hline
\end{tabular}

Note: RT - retention time; data on compounds content are expressed as peak area ( $\%$ of the total).

Fatty acids fraction in the Ch. cathayensis fruit cuticular waxes consisted of two long-chain compounds with an even carbon number $\left(\mathrm{C}_{16}\right.$ and $\mathrm{C}_{18}$ ), amounting only to $0.37 \%$ of the total. The alcohols fraction in Ch. cathayensis cuticular waxes mostly consisted of primary alcohols (three compounds in the range $\mathrm{C}_{18}-\mathrm{C}_{41}$ ), reaching $19.6 \%$ of the total amount. The fraction of fatty acid esters was represented by three compounds with an even and odd number of carbons in the range of $\mathrm{C}_{24}-\mathrm{C}_{57}$, accounting for $22.0 \%$ of total; of these, diisooctyl phthalate was the most abundant. Aldehydes in the cuticular waxes of Ch. cathayensis fruits were represented by six compounds with an even and odd numbers of carbons $\left(\mathrm{C}_{13}-\mathrm{C}_{30}\right)$, which amounted to $22.9 \%$ of total; heptacosanal and tricosanal were the main compounds among the aldehydes. Fraction of the alkanes and alkenes in the Ch. cathayensis fruit cuticular waxes consisted of three compounds $\left(\mathrm{C}_{8}-\mathrm{C}_{54}\right)$ dominated by tetrapentacontane and reached 
$23.3 \%$ of the total. Other compounds in the Ch. cathavensis fruit cuticular waxes included different triterpenoids and accounted for $6.2 \%$ of the total. Primary alcohols and esters accounted for $41.6 \%$, while the content of aldehydes and alkanes in total was $46.2 \%$ in the cuticular waxes of
Ch. cathayensis fruits. The phytochemicals study of Ch. $\times$ californica fruit cuticular waxes carried out by GC-MS analysis identified 23 individual compounds in the chloroformic extract. The sum of all identified components was $97.4 \%$ of the total amount (Table 4 ).

\section{Table 4}

Chemical constituents of chloroformic extracts of the $C h . \times$ californica fruit cuticular waxes

\begin{tabular}{|c|c|c|c|c|c|}
\hline Compound name & Formula & RT, min & Peak area, $\%$ & Classification & Bioactivity (References) \\
\hline Nonanal & $\mathrm{C}_{9} \mathrm{H}_{18} \mathrm{O}$ & 3.516 & 0.40 & aldehyde & not found \\
\hline 9-Oxononanoic acid & $\mathrm{C}_{9} \mathrm{H}_{16} \mathrm{O}_{3}$ & 4.566 & 0.41 & fatty acid & not found \\
\hline Cinnamaldehyde & $\mathrm{C}_{9} \mathrm{H}_{8} \mathrm{O}$ & 5.493 & 0.12 & aldehyde & antimicrobial (Ashakirin et al., 2017) \\
\hline $\begin{array}{l}\text { 3,7,11-Trimethyl-1,3,6,10-dodecatetraene } \\
\text { (syn. Alpha-Farnezene) }\end{array}$ & $\mathrm{C}_{15} \mathrm{H}_{24}$ & 6.042 & 0.45 & sesquiterpene & antimicrobial (Kuroda et al., 2007) \\
\hline Tetradecenal (syn. Myristaldehyde) & $\mathrm{C}_{14} \mathrm{H}_{28} \mathrm{O}$ & 7.612 & 0.23 & aldehyde & antimicrobial (Xianfei et al., 2007) \\
\hline 7-Hexadecenal & $\mathrm{C}_{16} \mathrm{H}_{30} \mathrm{O}$ & 7.632 & 1.38 & aldehyde & not found \\
\hline Hexadecanoic acid (syn. Palmitic acid) & $\mathrm{C}_{16} \mathrm{H}_{32} \mathrm{O}_{2}$ & 8.188 & 1.86 & fatty acid & antifungal (Pourakbar et al., 2021) \\
\hline Cis-9-Hexadecenal & $\mathrm{C}_{16} \mathrm{H}_{30} \mathrm{O}$ & 8.259 & 9.76 & aldehyde & antimicrobial (Hoda et al., 2020) \\
\hline E,E,Z-1,3,12-Nonadecatriene-5,14-diol & $\mathrm{C}_{19} \mathrm{H}_{34} \mathrm{O}_{2}$ & 9.285 & 1.21 & alcohol & antifungal (Parveen et al., 2017). \\
\hline Olean-12-ene-3,28-diol (3.beta) & $\mathrm{C}_{30} \mathrm{H}_{50} \mathrm{O}_{2}$ & 9.545 & 5.37 & triterpenoid & antimicrobial (Catteau et al., 2018) \\
\hline Undec-10-ynoic acid, tetradecyl ester & $\mathrm{C}_{25} \mathrm{H}_{48} \mathrm{O}_{2}$ & 9.960 & 1.82 & fatty acid ester & not found \\
\hline Eicosanal & $\mathrm{C}_{20} \mathrm{H}_{40} \mathrm{O}$ & 10.225 & 0.79 & aldehyde & not found \\
\hline Undec-10-ynoic acid, hexadecyl ester & $\mathrm{C}_{27} \mathrm{H}_{50} \mathrm{O}_{2}$ & 10.787 & 0.86 & fatty acid ester & not found \\
\hline Diisooctyl phthalate & $\mathrm{C}_{24} \mathrm{H}_{38} \mathrm{O}_{4}$ & 10.884 & 10.18 & fatty acid ester & antimicrobial (Shanab et al., 2010) \\
\hline Henicosanal & $\mathrm{C}_{21} \mathrm{H}_{42} \mathrm{O}$ & 11.233 & 2.44 & aldehyde & not found \\
\hline 2-Methyl-hexacosane & $\mathrm{C}_{27} \mathrm{H}_{56}$ & 11.549 & 1.68 & alkane & not found \\
\hline 1-Hentetracontanol & $\mathrm{C}_{41} \mathrm{H}_{84} \mathrm{O}$ & 12.176 & 6.65 & alcohol & not found \\
\hline Tricosanal & $\mathrm{C}_{23} \mathrm{H}_{46} \mathrm{O}$ & 12.534 & 3.83 & aldehyde & not found \\
\hline Lup-20(29)-en-3-ol (3. beta) (syn. Lupeol) & $\mathrm{C}_{30} \mathrm{H}_{50} \mathrm{O}$ & 12.601 & 1.60 & pentacyclic triterpenoid & antimicrobial (Catteau et al., 2018) \\
\hline Octacosanol & $\mathrm{C}_{28} \mathrm{H}_{58} \mathrm{O}$ & 12.801 & 1.10 & alcohol & anti-parkinsonism (Wang et al., 2010) \\
\hline Tetrapentacontane & $\mathrm{C}_{54} \mathrm{H}_{110}$ & 13.012 & 21.32 & alkane & not found \\
\hline Hexadecyl nonyl ether & $\mathrm{C}_{25} \mathrm{H}_{52} \mathrm{O}$ & 13.825 & 0.81 & ether & not found \\
\hline Heptacosanal & $\mathrm{C}_{27} \mathrm{H}_{54} \mathrm{O}$ & 14.364 & 23.14 & aldehyde & not found \\
\hline
\end{tabular}

Note: RT - retention time; data on compounds content are expressed as peak area ( $\%$ of the total).

Fatty acids in the Ch. $\times$ californica fruit cuticular waxes were represented by two compounds $\left(\mathrm{C}_{9}\right.$ and $\left.\mathrm{C}_{16}\right)$, amounting to $2.3 \%$ of total. The alcohol fraction in Ch. $\times$ californica fruit cuticular waxes mostly consisted of primary alcohols (two compounds, $\mathrm{C}_{25}$ and $\mathrm{C}_{41}$ ), reaching $7.8 \%$ of the total amount. The fatty acid esters were represented by three compounds with an even and odd carbons number $\left(\mathrm{C}_{24}-\mathrm{C}_{27}\right)$, equaling $12.9 \%$ of the total; among them, diisooctyl phthalate content was the highest. Aldehyde fraction in the fruit cuticular waxes of $\mathrm{Ch} . \times$ californica was represented by nine compounds with an even and odd carbon numbers $\left(C_{9}-C_{27}\right)$, which amounted to $42.1 \%$ of total; heptacosanal and cis-9hexadecenal were the main compounds among the aldehydes. Alkane fraction in the Ch. $\times$ californica fruit cuticular waxes consisted of two compounds $\left(\mathrm{C}_{27}-\mathrm{C}_{54}\right)$ dominated by tetrapentacontane and reached $23.0 \%$ of the total. Other compounds in the Ch. $\times$ californica fruit cuticular waxes included different triterpenoids and accounted for $7.4 \%$ of the total. Content of primary alcohols and esters was $20.6 \%$, while aldehydes and alkanes accounted for $65.1 \%$ in the cuticular waxes of $\mathrm{Ch} . \times$ californica fruits. Some chemical compounds with the well-known biological activity were identified in the fruit cuticular waxes of both Ch. cathayensis and Ch. $\times$ californica plants (Fig. 1).

\section{Discussion}

Fruit extracts of the Chaenomeles species are the rich source of phenolic compounds, including flavonoids and phenolic acids. However, distribution of these groups between the species and cultivars varies significantly depends on both genotype and environmental treats. The total content of polyphenols in the fruits of Ch. cathayensis slightly exceeded such in Ch. $\times$ californica fruits, while the accumulation of flavonoids and free phenolic acids prevailed more significantly (1.4 and 1.2 times respectively). Similar variability both of total polyphenols and the main bioactive compounds content was revealed in the fruits of five wild Chaenomeles species, namely Ch. japonica, Ch. sinensis, Ch. speciosa, Ch. cathayensis and Ch. thibetica (Du et al., 2013), and in Ch. speciosa fruits from four production areas in China (Zheng et al., 2018). Total contents of polyphenols determined in the fresh fruits of Ch. cathayensis and Ch. $\times$ californi$c a$ were comparable to such found in the dried fruits of Ch. speciosa
(Zheng et al., 2018) and Ch. japonica cultivars (Urbanaviciute et al., 2020). Reducing power capacity and total antioxidant activity also did not differ significantly in the fruits of Ch. cathayensis and Ch. $\times$ californica. The obtained results indicate the main dependence of the fruit antioxidant potential on the total polyphenols content, which was also confirmed by high correlation coefficients. In general, particularly the amount of polyphenols in plant extracts is associated with the antioxidant properties and different biological activities (Zakłos-Szyda \& Pawlik, 2018). Study of distribution of the phenolic compounds in peel and pulp of both Ch. $c a-$ thayensis and Ch. $\times$ californica fruits revealed significant dominane of fruit peel in the total contents of polyphenols, flavonoids and free phenolic acids. Findings are consistent with the data of Miao et al. (2018) that fruit peel of different Chaenomeles varieties contain more polyphenols, flavonoids and triterpenes, and show better antioxidant activity than flesh.

In the present study, we have found that the isopropanolic extracts from peel and pulp of both Ch. cathayensis and Ch. $\times$ californica fruits were active against all tested Gram-positive and Gram-negative bacteria, as well as against both Candida strains. These results confirm the well-known antimicrobial activity of Chaenomeles species, including a broad spectrum of antibacterial activity exhibited by the essential oil from the fruits of Ch. speciosa (Xianfei et al., 2007) and Ch. japonica (Urbanaviciute et al., 2020). Most of the tested bacterial strains were more sensitive to the inhibitory effect of the extracts from Ch. cathayensis fruits, whereas $P$. aeruginosa, $S$. aureus B904 and S. epidermidis ATCC149 strains were more effected by $C h . \times$ californica fruit extracts. $P$. aeruginosa strain was the most resistant to the action of both fruit extracts, especially peel extracts of $C h$. cathayensis fruits. Overall, compared to the peel extracts, the pulp extracts from the Ch. $\mathrm{Ca}$ thayensis fruits caused more notable growth inhibition of most bacterial strains except $E$. dissolvens and $E$. coli $\mathrm{B} 906$. However, no regularities were determined for the inhibitory effect of extracts from $C h$. $\times$ californica fruit peel and pulp. Similar differences in the antimicrobial activity between the fruit extracts of three $C h$. japonica cultivars were reported by Urbanaviciute et al. (2020), while none of the extracts showed antifungal activity against C. albicans yeast. In our study, both Ch. cathayensis and Ch. $\times$ californica peel and pulp fruit extracts exhibited equally high activities against $C$. albicans and $C$. lipolytica, indicating the feasibility of studying the antimicrobial potential of Chaenomeles fruits. 


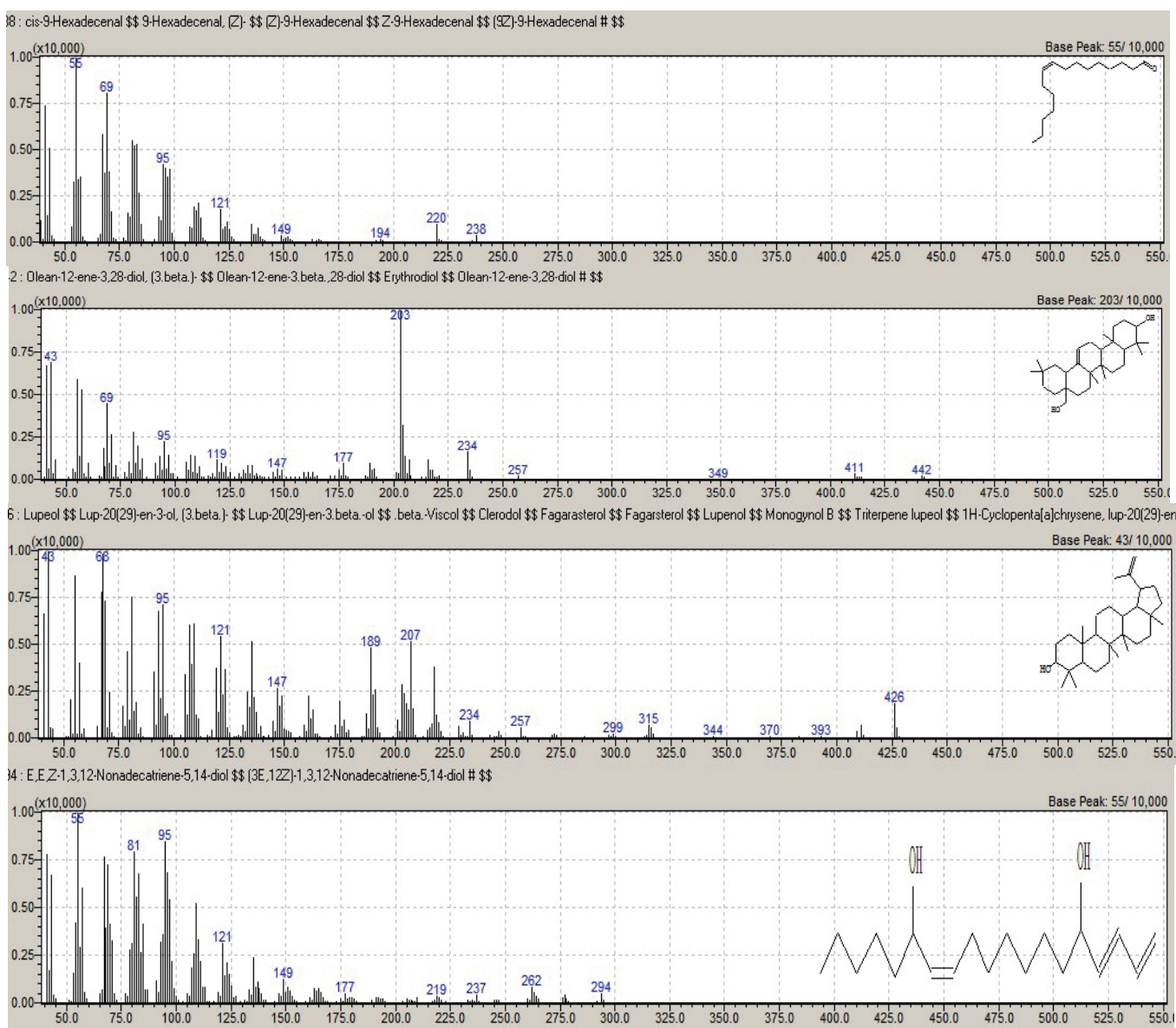

Fig. 1. Ch. cathayensis and $C h . \times$ californica fruit cuticular wax compounds having the known bioactivity: $a$-cis-9-hexadecenal, $b$ - olean-12-ene-3,28-diol (3. Beta), $c$-lupeol, $d$-1,3,12-nonadecatriene-5,14-diol

Results of GC-MS assays showed the presence of the fatty acids, aldehydes, alkanes, esters, alcohols and different terpenoids in compositions of cuticular waxes of both Ch. cathayensis and Ch. $\times$ californica fruits. However, the amount of these compounds varies significantly, confirming the known data (Trivedi et al., 2019; Lykholat et al., 2021) that the fruit cuticular wax chemical composition varies greatly between fruit species and is modified by developmental and environmental cues affecting the wax protective properties. Identification of the fruit cuticular waxes component composition of Ch. cathayensis and Ch. $\times$ californica revealed the chemical compounds that have known biological activities. Cinnamaldehyde identified in $\mathrm{Ch} . \times$ californica cuticular wax was represented (Ashakirin et al., 2017) as a new antibacterial agent which exerted substantial antimicrobial activity. Oleic acid found in Ch. cathayensis fruit cuticular waxes is known as bioactive compounds having antifungal activities against plant pathogenic fungi (Walters et al., 2004), and cancer prevention (Diab et al., 2021). Moreover, Zheng et al. (2005) showed that antibacterial activity of long-chain unsaturated fatty acids, such as oleic acid, is mediated by the inhibition of bacterial fatty acid synthesis. Diisooctyl phthalate that was found in great amount in the cuticular waxes of both Ch. cathayensis and Ch. $\times$ californica fruits was reported by Shanab et al. (2010) as an antimicrobial agent along with many other phthalates. Triterpenoids olean-12-ene-3,28-diol (3.beta) and lupeol identified in the waxes of both species are known (Catteau et al., 2018) for their antimicrobial activity. The presence of the mentioned bioactive compounds in the fruit cuticular waxes suggests their involvement in the bioactivity of extracts from Ch. cathayensis and Ch. $\times$ californica fruit. Further research is needed to detect the bioactivity of fruit extracts and identify compounds responsible for certain effects.

\section{Conclusion}

Peel and pulp of Ch. cathayensis and Ch. $\times$ californica fruits can accumulate high contents of polyphenols, flavonoids and free phenolic acids. They showed substantial antimicrobial activities against all selected bacterial and fungal strains. The detectable amounts of cinnamaldehyde, oleic acid, hexadecanoic acid, and some triterpenes, which are wellknown as bioactive compounds, were found in the fruit cuticular waxes. Antimicrobial effects of the fruit extracts against four Gram-negative, five Gram-positive bacteria and two fungal strains varied between peel and pulp fruit extracts of both plant species. The findings confirmed the healthpromoting abilities of the fruits of Ch. cathayensis and Ch. $\times$ californica plants, and also indicated the implementation of these useful properties by the introduced plants in unfavorable climatic conditions.

\section{References}

Ashakirin, S. N., Tripathy, M., Patil, U. K., \& Majeed, A. B. A. (2017). Chemistry and bioactivity of cinnamaldehyde: A natural molecule of medicinal importance. International Journal of Pharmaceutical Sciences and Research, 8(6), 2333-2340.

Baranowska-Bosiacka, I., Bosiacka, B., Rast, J., Gutowska, I., Wolska, J., RębaczMaron, E., Dębia, K., Janda, K., Korbecki, J., \& Chlubek, D. (2017). Macroand microelement content and other properties of Chaenomeles japonica $\mathrm{L}$. fruit and protective effects of its aqueous extract on hepatocyte metabolism. Biological Trace Element Research, 178, 327-337.

Begum, I. F., Mohankumar, R., Jeevan, M., \& Ramani, K. (2016). GC-MS analysis of bio-active molecules derived from Paracoccus pantotrophus FMR19 and the antimicrobial activity against bacterial pathogens and MDROs. Indian Journal of Microbiology, 56(4), 426-432.

Bhimba, B. V., Pushpam, A. C., Arumugam, P., \& Prakash, S. (2012). Phthalate derivatives from the marine fungi Phoma herbarum VB7. International Journal of Biological and Pharmaceutical Research, 3(4), 507-512.

Buschhaus, C., Herz, H., \& Jetter, R. (2007). Chemical composition of the epicuticular and intracuticular wax layers on adaxial sides of Rosa canina leaves. Annals of Botany, 100(6), 1557-1564.

Catteau, L., Zhu, L., Van Bambeke, F., \& Quetin-Leclercq, J. (2018). Natural and hemi-synthetic pentacyclic triterpenes as antimicrobials and resistance modifying agents against Staphylococcus aureus: A review. Phytochemistry Reviews, $17,1129-1163$ 
Diab, T. A., Donia, T., \& Saad-Allah, K. M. (2021). Characterization, antioxidant, and cytotoxic effects of some Egyptian wild plant extracts. Beni-Suef University Journal of Basic and Applied Sciences, 10, 13.

Do Nascimento, P. G. G., Lemos, T. L. G., Bizerra, A. M. C., Arriaga, Â. M. C., Ferreira, D. A., Santiago, G. M. P., Braz-Filho, R., \& Costa, J. G. M. (2014). Antibacterial and antioxidant activities of ursolic acid and derivatives. Molecules, 19(1), 1317-1327.

Du, H., Wu, J., Li, H., Zhong, P. X., Xu, Y. J., Li, C. H., Ji, K. X., \& Wang, L. S. (2013). Polyphenols and triterpenes from Chaenomeles fruits: Chemical analysis and antioxidant activities assessment. Food Chemistry, 141, 4260-4268.

Gawron-Gzella, A., Dudek-Makuch, M., \& Matlawska, I. (2012). DPPH radical scavenging activity and phenolic compound content in different leaf extracts from selected blackberry species. Acta Biologica Cracoviensia, Series Botanica, 54(2), 32-38.

Gorlach, S., Wagner, W., Podsędek, A., Szewczyk, K., Koziołkiewicz, M., \& Dastych, J. (2011). Procyanidins from japanese quince (Chaenomeles japonica) Fruit induce apoptosis in human colon cancer caco-2 cells in a degree of polymerization-dependent manner. Nutrition and Cancer, 63(8), 1348-1360.

Han, Y.-K., Kim, Y.-S., Natarajan, S. B., Kim, W.-S., Hwang, J.-W., Jeon, N.-J., Jeong, J.-H., Moon, S.-H., Jeon, B.-T., \& Park, P.-J. (2016). Antioxidant and anti-inflammatory effects of Chaenomeles sinensis leaf extracts on LPS-stimulated RAW 264.7 cells. Molecules, 21(4), 422.

Hoda, S., Gupta, L., Shankar, J., Gupta, A. K., \& Vijayaraghavan, P. (2020). cis-9Hexadecenal, a natural compound targeting cell wall organization, critical growth factor, and virulence of Aspergillus fumigatus. ACS Omega, 5(17), 10077-10088.

Khromykh, N., Lykholat, Y., Shupranova, L., Kabar, A., Didur, O., Lykholat, T., \& Kulbachko, Y. (2018). Interspecific differences of antioxidant ability of introduced Chaenomeles species with respect to adaptation to the steppe zone conditions. Biosystems Diversity, 26(2), 132-138.

Kuroda, M., Nagasaki, S., \& Ohta, T. (2007). Sesquiterpene farnesol inhibits recycling of the C55 lipid carrier of the murein monomer precursor contributing to increased susceptibility to beta-lactams in methicillin-resistant Staphylococcus aureus. Journal of Antimicrobial Chemotherapy, 59, 425-432.

Lewandowska, U., Szewczyk, K., Owczarek, K., Hrabec, Z., Podsędek, A., Koziołkiewicz, M., \& Hrabec, E. (2013). Flavanols from japanese quince (Chaenomeles japonica) fruit inhibit human prostate and breast cancer cell line invasiveness and cause favorable changes in Bax/Bcl-2 mRNA ratio. Nutrition and Cancer, 65(2), 273-285.

Lykholat, Y. V., Khromykh, N. O., Didur, O. O., Davydov, V. R., Sklyar, T. V., Drehval, O. A., Vergolyas, M. R., Verholias, O. O., Marenkov, O. M., Nazarenko, M. M., Lavrentieva, K. V., Kurahina, N. V., Lykholat, O. A., Legostaeva, T. V., Zaytseva, I. O., Kabar, A. M., \& Lykholat, T. Y. (2021). Features of the fruit epicuticular waxes of Prunus persica cultivars and hybrids concerning pathogens susceptibility. Ukrainian Journal of Ecology, 11(1), 261-266.

Lykholat, Y. V., Khromykh, N. O., Lykholat, T. Y., Didur, O. O., Lykholat, O. A., Legostaeva, T. V., Kabar, A. M., Sklyar, T. V., Savosko, V. M., Kovalenko, I. M., Davydov, V. R., Bielyk, Y. V., Volyanik, K. O., Onopa, A. V., Dudkina, K. A., \& Grygoryuk, I. P. (2019). Industrial characteristics and consumer properties of Chaenomeles Lindl. fruits. Ukrainian Journal of Ecology, 9(3), 132-137.

Lykholat, Y. V., Khromykh, N. O., Pirko, Y. V., Alexeyeva, A. A., Pastukhova, N. L., \& Blume, Y. B. (2018). Epicuticular wax composition of leaves of Tilia L. trees as a marker of adaptation to the climatic conditions of the steppe Dnieper. Cytology and Genetics, 52, 323-330.

Ma, B., Wang, J., Tong, J., Zhou, G., Chen, Y., He, J., \& Wang, Y. (2016). Protective effects of Chaenomeles thibetica extract against carbon tetrachloride-induced damage via the MAPK/Nrf2 pathway. Food and Function, 7(3), 1492-1500.

Miao, J., Li, X., Zhao, C., Gao, X., Wang, Y., \& Gao, W. (2018). Active compounds, antioxidant activity and alpha-glucosidase inhibitory activity of different varieties of Chaenomeles fruits. Food Chemistry, 248, 330-339.

Miao, J., Zhao, C., Li, X., Chen, X., Mao, X., Huang, H., Wang, T., \& Gao, W. (2016). Chemical composition and bioactivities of two common Chaenomeles fruits in China: Chaenomeles speciosa and Chaenomeles sinensis. Journal of Food Science, 81, H2049-H2058.

Ololade, Z. C., Essien, E. R., \& Agboola, O. O. (2015). Pharmacological potential of the stem extract of Melissa officinalis: Compositional profile, polyphenol, ascorbic acid contents, antioxidant, anti-inflammatory and antimicrobial activities. Bells University Journal of Applied Sciences and Environment, 1(2), 43-52.
Parveen, Z., Mazhar, S., Siddique, S., Manzoor, A., \& Ali, Z. (2017). Chemical composition and antifungal activity of essential oil from Xanthium strumarium L. leaves. Indian Journal of Pharmaceutical Sciences, 79(2), 316-321.

Pękal, A., \& Pyrzynska, K. (2014). Evaluation of aluminum complexation reaction for flavonoid content assay. Food Analytical Methods, 7, 1776-1782.

Pourakbar, L., Moghaddam, S. S., El Enshasy, H. A., \& Sayyed, R. Z. (2021). Antifungal activity of the extract of a macroalgae, Gracilariopsis persica, against four plant pathogenic fungi. Plants, 10(9), 1781.

Prieto, P., Pineda, M., \& Aguilar, M. (1999). Spectrophotometric quantitation of antioxidant capacity through the formation of a phosphomolybdenum complex: Specific application to the determination of vitamin E. Analytical Biochemistry, 269(2), 337-341.

Pulido, R., Bravo, R. L., \& Saura-Calixto, F. (2000). Antioxidant activity of dietary polyphenols as determined by a modified ferric reducing/antioxidant power assay. Journal of Agricultural and Food Chemistry, 48, 3396-3402.

Rumpunen, K. (2002). Chaenomeles: Potential new fruit crop for northern Europe. In: Janick, J., \& Whipkey, A. (Eds.). Trends in New Crops and New Uses. ASHS Press, Alexandria. Pp. 385-392.

Shanab, S. M. M., Shalaby, E. A., Lightfoot, D. A., \& El-Shemy, H. A. (2010). Allelopathic effects of water hyacinth [Eichhornia crassipes]. PLoS One, 5(10), e13200.

Singleton, V. L., Orthofer, R., \& Lamuela-Raventos, R. M. (1999). Analysis of total phenols and other oxidation substrates and antioxidants by means of FolinCiocalteau reagent. Methods in Enzymology, 299, 152-178.

Suh, W. S., Park, K. J., Kim, D. H., Subedi, L., Kim, S. Y., Choi, S. U., \& Lee, K. R. (2017). A biphenyl derivative from the twigs of Chaenomeles speciosa. Bioorganic Chemistry, 72, 156-160.

Trivedi, P., Nguyen, N., Hykkerud, A. L., Häggman, H., Martinussen, I., Jaakola, L., \& Karppinen, K. (2019). Developmental and environmental regulation of cuticular wax biosynthesis in fleshy fruits. Frontiers in Plant Science, 10, 431.

Urbanaviciute, I., Liaudanskas, M., Bobinas, C., Šarkinas, A., Rezgiene, A., \& Viskelis, P. (2020). Japanese quince (Chaenomeles japonica) as a potential source of phenols: Optimization of the extraction parameters and assessment of antiradical and antimicrobial activities. Foods, 9, 1132.

Walters, D., Raynor, L., Mitchell, A., Walker, R., \& Walker, K. (2004). Antifungal activities of four fatty acids against plant pathogenic fungi. Mycopathologia, 157(1), 87-90.

Wang, T., Liu, Y.-Y., Wang, X., Yang, N., Zhu, H.-B., \& Zuo, P.-P. (2010). Protective effects of octacosanol on 6-hydroxydopamine-induced parkinsonism in rats via regulation of ProNGF and NGF signaling. Acta Pharmacologica Sinica, 31(7), 765-774.

Xianfei, X., Xiaoqiang, C., Shunying, Z., \& Guolin, Z. (2007). Chemical composition and antimicrobial activity of essential oils of Chaenomeles speciosa from China. Food Chemistry, 100(4), 1312-1315.

Yeung, H.-C. (2000). Handbook of Chinese herbs and formulas. Redwing Book Co., Taos.

Zakłos-Szyda, M., \& Pawlic, N. (2018). Japanese quince (Chaenomeles japonica L.) fruit polyphenolic extract modulates carbohydrate metabolism in HepG2 cells via AMP-activated protein kinase. Acta Biochimica Polonica, 65(1), 67-68.

Zhang, S. Y., Han, L. Y., Zhang, H., \& Xin, H. L. (2014). Chaenomeles speciosa: A review of chemistry and pharmacology. Biomedical Reports, 2, 12-18.

Zheng, C. J., Yoo, J. S., Lee, T. G., Cho, H. Y., Kim, Y. H., \& Kim, W. G. (2005) Fatty acids synthesis is a target for antibacterial activity of unsaturated fatty acids. FEBS Letters, 579(23), 5157-5162.

Zheng, X., Wang, H., Zhang, P., Gao, L., Yan, N., Li, P., Liu, X., Du, Y., \& Shen, G. (2018). Chemical composition, antioxidant activity and $\alpha$-glucosidase inhibitory activity of Chaenomeles speciosa from four production areas in China. Molecules, 23(10), 2518.

Zubair, M. F., Atolani, O., Ibrahim, S. O., Adebisi, O. O., Hamid, A. A., \& Sowunmi, R. A. (2017). Chemical constituents and antimicrobial properties of Phyllanthus amarus (Schum \& Thonn). Bayero Journal of Pure and Applied Sciences, $10(1), 35$.

Zvikas, V., Urbanaviciute, I., Bernotiene, R., Kulakauskiene, D., Morkunaite, U., Balion, Z., Majiene, D., Liaudanskas, M., Viskelis, P., Jekabsone, A., \& Jakstas, V. (2021). Investigation of phenolic composition and anticancer properties of ethanolic extracts of japanese quince leaves. Foods, 10, 18. 